\title{
Acquired non-Chagas megacolon associated with the use of psychiatric medication: case report and differential diagnosis with Chagas megacolon
}

\section{Megacólon adquirido não chagásico associado ao uso de medicação psiquiátrica: relato de caso e diagnóstico diferencial com megacólon chagásico}

\author{
Sheila Jorge Adad ${ }^{1}$, Moisés Amâncio Souza², Gisele Barbosa e Silva ${ }^{3}$, José do Carmo Junior², \\ Charles Antônio Pires de Godoy ${ }^{1}$ and Adilha Misson Rua Micheletti ${ }^{1}$
}

\begin{abstract}
A case of acquired megacolon in a 62 -year-old man with acute abdomen due to sigmoid volvulus is reported. The case was associated with the use of psychiatric medications. The aim in this report was to emphasize the differential diagnosis with Chagas megacolon. Anatomopathological examination did not show any evidence of denervation, ganglionitis and/or myositis, and the serological test for Chagas disease was negative.
\end{abstract}

Key-words: Acquired megacolon. Psychiatric medications. Chagas disease.

\section{RESUMO}

Relata-se caso de megacólon adquirido, associado ao uso de medicamentos psiquiátricos, em homem de 62 anos, com abdome agudo por volvo de sigmóide, com o objetivo de destacar o diagnóstico diferencial de megacólon chagásico. 0 exame anátomo-patológico não evidenciou denervação, ganglionite e/ou miosite e a sorologia para doença de Chagas foi negativa.

Palavras-chaves: Megacólon adquirido. Medicamentos psiquiátricos. Doença de Chagas.

The condition of megacolon is characterized by intestinal dilatation accompanied by wall thickening ${ }^{6}$ or increased muscle mass $^{1}$, in the absence of mechanical obstruction. When it is manifested in childhood, which is often from birth onwards, the most likely explanation is that it is a result of congenital aganglionosis (Hirschsprung's disease) ${ }^{11}$. In adulthood, the most frequent cause is related to hypoganglionosis due to Chagas disease $^{1}$. On rare occasions, it is associated with other causes such as neurological disorders, myxedema, infiltrative diseases, scleroderma or neuroleptic drugs 5 .

The frequency of enlarged organs in chronic Chagas disease patients varies from region to region. It is a common condition in the Triangulo Mineiro region (westernmost part of the State of Minas Gerais, Brazil), where it occurs in around 10\% of Chagas disease patients ${ }^{4}$. On the other hand, idiopathic megacolon is rare throughout the world. For this reason, when acquired megacolon is observed in our region, Chagas disease etiology is always thought of first. Sometimes, simple tests like the serological test for Chagas disease are not even requested and Chagas etiology is attributed empirically.

\section{CASE REPORT}

This was a 62-year-old male patient with a history of diffuse colicky abdominal pain associated with abdominal distension who had not been able to eliminate flatus and feces for four days. He said that he had not had any nausea, vomiting, previous similar episodes, previous abdominal surgery, feelings of incomplete evacuation, ribbonlike feces or proctalgia. He said that he had had daily intestinal evacuation habits, without abnormalities. He said that did not have any antecedents of Chagas disease or diabetes mellitus. He had had hypertension for a long time and was using captopril and hydrochlorothiazide. He was a chronic alcoholic who had consumed one bottle of spirits per day for 55 years. His history included admission to a psychiatric hospital eight years

\footnotetext{
1. Patologia Especial, Universidade Federal do Triângulo Mineiro, Uberaba, MG. 2. Cirurgia, Universidade Federal do Triângulo Mineiro, Uberaba, MG. 3. Bolsista de Iniciação Científica (CNPq), Ministério de Ciências e Tecnologia, Uberaba, MG.

Apoio financeiro: CNPq (479335/2006-0) - Bolsa PIBIC e Produtividade em Pesquisa.

Address to: Dra. Sheila J. Adad. Dept ${ }^{\circ}$ Patologia Especial/UFTM. Rua Getúlio Guaritá 130, Bairro Abadia, 38025-440 Uberaba, MG.

Tel: $55343318-5152$

e-mail: sheila.adad@gmail.com

Recebido para publicação em: 31/01/2008

Aceito em: 15/05/2008
} 
earlier, from which he was discharged with prescriptions for the medications haloperidol, diazepam and promethazine.

Upon physical examination, he was in a good state: hydrated, acyanotic, non-jaundiced, non-febrile, underweight and with normal coloration. His lungs were clean and eupneic. His heartbeat was regular, with a rate of 76 beats per minute and arterial pressure of $120 \times 80 \mathrm{mmHg}$. His abdomen was rounded, tense and hypertympanic. The abdominal X-ray showed significant distension of the colon loops, with the presence of a dilated sigmoid and the omega sign, and with the convex part of the loop located far from the point of obstruction. The chest x-ray was normal.

Endoscopic decompression was performed. However, because the condition recurred, Hartmann's colectomy was then carried out. During the operation, the presence of dolichomegacolon was observed, with colon distension extending as far as the cecum, in association with sigmoid volvulus without evident signs of ischemia. A clinical hypothesis of Chagas megacolon was made. Nevertheless, the serological test for this disease was not performed.

A segment of the large intestine fixed in formol was sent for anatomopathological examination. This segment was $60 \mathrm{~cm}$ in length and consisted of the descending colon, sigmoid and proximal part of the rectum. It had a dilated appearance, with a maximum circumference of $19 \mathrm{~cm}$ in the middle portion of the sigmoid. The tapeworms were spread out in the sigmoid. The wall was firm and thickened $(0.2 \mathrm{~cm})$. The appearance was compatible with what is seen macroscopically in cases of Chagas megacolon. However, microscopically, no abnormalities suggestive of Chagas etiology were seen, such as hypoganglionosis, myositis and/or chronic ganglionitis (Figures 1 and 2). There were only sparse ischemic cells, rare mitoses in the muscle

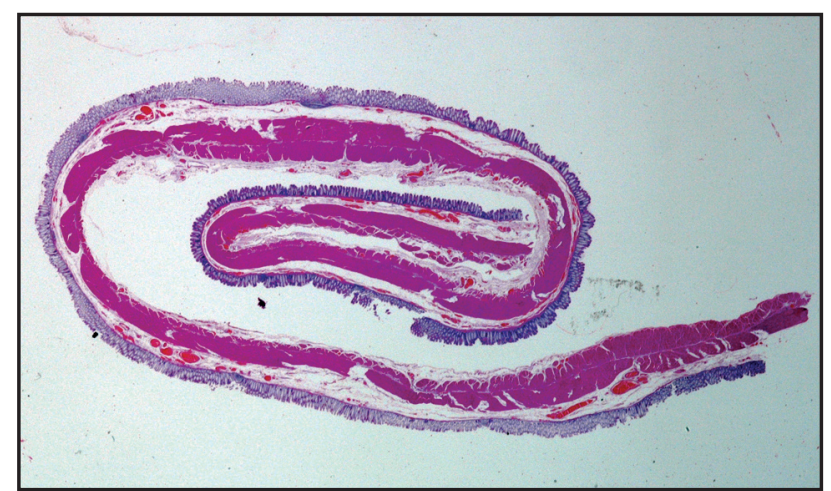

Figure 1 - Macroscopic photograph of histological section through the middle portion of the sigmoid, in which the intestinal ring was twisted on itself. Note the increased circumference and hypertrophy of the muscle tissue, as would be observed in cases of megacolon.

tissue, slight muscle hypertrophy and hypertrophy of the neuron perikarya. New subserial histological sections were made from complete intestinal rings at the rectosigmoid transition, the middle portion of the sigmoid and the descending colon-sigmoid transition, in accordance with the methodology used for neuron counting $^{2}$. No denervation or inflammation were found. Since the anatomopathological examination was not suggestive of Chagas

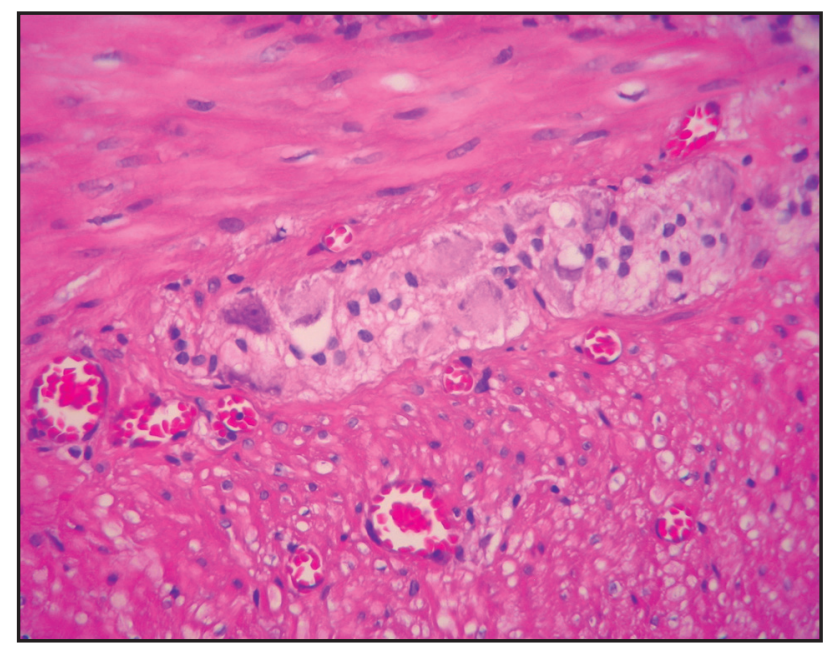

Figure 2 - Photomicrograph of the same region of the sigmoid. Note the absence of myositis and normal quantities of neuroms in the myenteric plexus.

disease etiology, a reassessment of the patient was requested. The serological test for Chagas disease was then performed, which gave a negative result (ELISA, indirect immunofluorescence and passive hemagglutination). Although failures may occur in the serological test, and rare negative cases exist ${ }^{8}$, the clinical picture was also not the usual one for this disease, since there were no antecedents of intestinal constipation, even though this may occur in Chagas megacolon patients.

\section{DISCUSSION}

When we make a diagnosis of megacolon in our environment, which may take place in a situation of urgency because of complications such as fecaloma or sigmoid volvulus, we generally think of Chagas disease etiology because of the continuing high prevalence of this disease ${ }^{5}$. However, other causes of chronic intestinal constipation must also be borne in mind, such as the use of drugs like antacids (aluminum hydroxide and calcium carbonate), anticholinergics (pectin), antidiarrhetics (casein), antiparkinsonians, antidepressives (tricyclics or lithium), antihypertensives/ antiarrhythmics (calcium channel blockers), metals (bismuth, iron or heavy metals), opioids, laxatives, nonsteroidal anti-inflammatory drugs or sympathicomimetics (pseudoephedrine $)^{12}$. In the present case report, the patient presented a clinical condition of sigmoid volvulus that did not respond to conservative treatment and required urgent decompression surgery. The macroscopic appearance of the specimen was similar to what is seen in cases of Chagas megacolon. Nonetheless, the microscopic abnormalities were incompatible with Chagas or congenital megacolon. The serological test was negative for Chagas disease. When we analyzed the patient's history, we found that he had been making chronic use of drugs that could interfere with neuronal activity, such as diazepam, haloperidol and promethazine, and these were the probable cause of this patient's megacolon. There have been reports that these drugs may be related to chronic intestinal constipation and probably to megacolon $^{37910}$. We therefore concluded that the present case of megacolon was probably triggered by the use of medications. 
In conclusion, it is important to emphasize that even in areas that are epidemiologically positive for Chagas disease, it is essential to perform tests to prove Chagas etiology and make a differential diagnosis with other possible etiologies.

\section{REFERENCES}

1. Adad SJ. Contribuição ao estudo da anatomia patológica e da patogênese do megacólon chagásico. Tese de Doutorado, Faculdade de Medicina do Triângulo Mineiro, Uberaba, MG, 1996.

2. Adad SJ, Cançado CG, Etchebehere RM, Teixeira VPA, Gomes UA, Chapadeiro E, Lopes ER. Neuron count reevaluation in the myenteric plexus of chagasic megacolon after morphometric neuron analysis. Virchows Archives 438: 254-258, 2001.

3. Cumsille GB, Pisano RV. Aspectos clínicos, radiológicos e histopatológicos del megacolon del adulto en Chile: análisis de 100 casos. Revista Chilena de Cirurgía 48: 42-49, 1996.
4. Cutait D. Megacólon. In: Coelho JCU (ed) Aparelho Digestivo. Clínica e Cirurgia, $2^{a}$ edição, Editora Medsi, Rio de Janeiro, p. 665-680, 1996.

5. Haubrich WS, Schaffner F, Berk JE. Bockus Gastroenterology. WB Saunders Co, Philadelphia, 1995.

6. Köberle F. Chagas' disease and Chagas' syndromes: the pathology of American trypanosomiasis. Advances in Parasitology 6: 63-116, 1968.

7. Lim DK, Mahedran R. Risperidone and megacolon. Singapore Medical Journal 43: 530-532, 2002.

8. Luquetti AO. Megaesôfago e anticorpos anti-trypanossoma cruzi. Revista Goiana de Medicina 33:1-16, 1987.

9. Preston DM, Jones JEL, Thomas BM. Towards. A radiologic definition of idiopathic megacolon. Gastrointestinal Radiology 10: 167-169, 1985.

10. Ross JP, Small TR, Lepage PA. Imipramine overdose complicated by toxic megacolon. The American Surgeon 64: 242-244, 1998.

11. Santos Júnior JCM. Megacólon - Parte I: Doença de Hirschsprung. Revista Brasileira de Coloproctologia 3:196-209, 2002.

12. Santos Júnior JCM. Laxantes e Purgativos - O Paciente e a Constipação Intestinal. Revista Brasileira de Coloproctologia 23: 130-134, 2003. 